\title{
Value Chain Analysis of Coffee: Key for Upgrading the Smallholder Farmers in Sidama Zone of SNNPRS
}

\author{
Sintayehu Assefa (PhD Candidate) \\ Department of Management, University of Hawassa - Ethiopia
}

\begin{abstract}
Smallholder farmers in developing countries like Ethiopia need to improve their position for agricultural products like coffee in order to improve productivity and profitability through innovations within the chains. The study was conducted to analyze the coffee value chain in Sidama Zone of SNNPRS. Both primary and secondary data were used. Descriptive statistics, value chain mapping and econometric methods were employed to analyze the data. Proportional stratified random sampling techniques for farmers and random sampling techniques for traders were used. To analyze the collected data the Statistical Package for Social Sciences (SPSS) version 21 was used. The result of value added activities among the major value chain actors showed that all actors involved in the coffee value chain were adding value to the product; processors were the dominant in adding value (47.58\%). In addition, the study also disclosed that six value chain actors: Farmers, Collectors, Wholesalers, Retailers, Processors and Consumers were identified. Result from econometric analysis indicates that four variables are significantly affecting value chain and education has a positive and significant effect with value of beta $=0.573$ whereas age of plantation has negative (-0.025). The findings also indicated that farmers faced with production, marketing and transportation problems among which poor disease control, low irrigation facility, low supply of coffee seed, low price of coffee, price fluctuations, brokers interference, shortage of truck and high transportation cost. Therefore, the findings of the study underscore strengthening extension service, sharing experience among farmers, increase production and productivity and strengthening input supply, increase the proportion of coffee selling at significant premiums, timely updated and sustainable market information services, coffee quality improvement, solving existing problems of hulling machine, and cooperatives expansion as important policy issues to improve coffee value chain in the study area.
\end{abstract}

Keywords: Coffee, Sidama Zone, Value Chain Mapping, Value chain Analysis

DOI: $10.7176 /$ FSQM/112-01

Publication date: January $31^{\text {st }} 2022$

\subsection{Introduction}

Value chain plays a great role in understanding how inputs and services brought to manufacture a product, how products moves from producers to consumers and then how value can be added (Webber \& lambaste, 2010). To note some before entering in to some details, in the study, coffee, as it is stated in Oxfam (2009) is an important cash crop commodity which is highly traded worldwide next to petroleum, supplied by smallholder producers who live in 80 countries like that of Latin America, Africa and Asia. In global coffee market, there are two types of coffee traded named as Coffee Arabic and Coffee Robust (ICO, 2009). From these Arabic type is considered a fine quality and sold as specialty types of coffee at higher premium than Robust in international coffee market (Hailu, 2007).

According to Daviron and Ponte (2005) more than $90 \%$ of all coffee bean production takes place in less developed countries like Brazil, even though most of the value adding and consumption takes place in the most developed countries; therefore, coffee trade characterizes how global commodity chains are built up and how value adding is distributed alongside the value chain. Furthermore, the significance of coffee is confirmed by the fact that for most of the post Second World War age, coffee has been second only to oil when ranking the accumulated value of traded commodities in the world market.

Parallel to the report of Singh et al (2006) consumption of coffee in markets like Europe, Japan and North America is growing at less than two percent per year while consumption in Brazil, China and India is growing at an extraordinary annual rate of $10 \%$ to $20 \%$. In all these markets one segment that is enjoying strong growth is specialty coffee, as many consumers are trading up to higher quality beans and moving away from commercialgrade coffee.

With regard to Oxfam (2002) study report, the economic growth of many developing countries is tied with coffee production and other primary commodities. This study further indicated that, in Africa there are 25 coffee producing countries of which Ethiopia is one of the largest producer and exporter. However, in the country where coffee is produced the coffee producers' livelihood and their government revenue largely depend on coffee export price as a means to earn foreign exchange. As a result of this, when price of coffee collapses in international market, this country's coffee producers and government faces difficulties to settle their liability and also makes the government unable to provide the needed investment in infrastructure, health service and educational provision (Oxfam, 2002). 
Coffee is considered as a major exported commodity of Ethiopia and also it is estimated that above $25 \%$ of Ethiopian population depends directly or indirectly on coffee farming and processing activities (Babur, 2009). Moreover, Ethiopia was accounted as origin and center of diversified coffee Arabic types of coffee which was discovered in southwest highland tropical areas of the country (Hailu, 2007).

With regard to the report of ITC (2002) Ethiopia is probably the oldest exporter of coffee in the world and the sixth largest coffee producer after Brazil, Colombia, Vietnam, Indonesia and India, and the seventh largest exporter worldwide. It is the largest coffee producer and exporter in Africa. But according to Roukens (2005) Ethiopia's contribution of coffee exported to the world market is so far insignificant.

Moreover, agribusiness value chain is expected to generate surplus primarily for the producer to secure better purchasing capacity, secondly for the development of other sectors as a source of raw materials, and thirdly as a means of obtaining hard currency for the technology that is imported (Baloyi, 2010). That is why the government of Ethiopia set a market oriented production system strategy. This is useful for small scale farmers, group of farmers like co-operatives as well as the nation as a whole through provision of fair benefit to all actors of the chain in the market. Having this background, coffee value chain plays a vital role in improving production, food security and upgrading the chain of small farmer producer of coffee (Daviron \& Ponte 2005).

Having said this, for efficient and functional system to occur focus should be made to local activities in bringing the product from production stage to consumption by assessing the value chain with existing channel and the different actors of it (Kaplinsky \& Morris, 2002). This could promote and strengthen farmers based institutions like farmers group, co-operatives, private institutions in the production of and value addition so that a sustainable growth will be achieved among the smallholder producers of farmers. Here, in the study area the existing value chain is not studied and the availability of documents also in short supply.

Therefore, this study is mainly focused on value chain analysis of coffee in Dale, Sidama Zone. The stated study area is well known in the production of coffee in SNNPRS. But in the study area there is also shortage of documents concerning the value chain and the government bodies especially the bureaus of agriculture in the study area do not have sufficient documents concerning how the coffee value chain can serve as either in income generating capacity or improve smallholder producer position in the value chain of coffee. To state one, Demeke (2007) studied on Performance of coffee marketing co-operatives and members' satisfaction in Dale District and the focus of the study is on satisfaction level of coffee farmers' marketing co-operatives but failed to deal with governance, upgrading and distributional issues of value chain especially in measuring the chain performance. Thus, the researcher is motivated to conduct research in the study area to fill such gaps. Consequently, this study provides information on, Who are the actors in the map of coffee value chain in study area? What are the opportunities and constraints along the coffee value chain? What are the factors that affect the market supply of coffee? And help to improve smallholder producer position in the value chain of coffee in the study area.

\subsection{Statement of the problem}

Ethiopian coffee has a reputation for high quality coffee. However, not all Ethiopian coffee producers are able to capture the benefits associated with producing and marketing a premium quality product. This owes to constraints to production, processing, storage and both domestic and international market functioning. In production, coffee farmers face challenges around land (cost, availability, and quality), water (cost, timeliness/seasonality), marketed inputs (availability, timeliness, cost, and quality), access to credit, availability of appropriate technical advice including timely and affordable response to pests and diseases. Quality losses also occur in poor post-harvest onfarm processing, including weak storage infrastructure and contamination with other products (Jemal, 2013).

In another interrelated study made by Zerihun and Tadesse (2009) coffee exported through the official channels passes through a number of value chain actors before it reaches final consumers. Here, the domestic coffee value chain is currently controlled by companies locally called "sebsabis" (who gather coffee from producers), "akrabies" (who purchase coffee from "sebsabies" and supply the auction market) and exporters. In Dale Woreda of Sidama Zone, the coffee farmers are selling to the coffee collectors, suppliers, service cooperatives, and retailers and even directly to local consumers (Zerihun \& Tadesse, 2009).

As far as coffee value chain is concerned, Tadesse et al. (2007) pointed out Yirgachefe and Harar coffee types are considered price leaders due to their superiority in price and quality compared to other coffee types both in the local and export markets. Moreover, Willem (2011) also reported presence of a particular demand for Harar coffee in Saudi Arabia. However, the country is not benefited from this product because Harar coffee was blended (adulterated) with other zones coffees, and the value adding practice is almost negligible as sited in (Jemal, 2013).

The smallholder producers' market access is currently in the study area limited due to low level of production, poor product quality (attributed to poor harvesting, processing, and handling practices), adulteration, weak bargaining power, little market information, low market supply and market barriers. Therefore, assessment of value chain is an essential prerequisite to find out the likely reasons that limit the overall performance of value chain and marketing of coffee and come up with specific workable solutions. Keeping in mind the above gaps, the research answered the following questions 
- What are the factors that affect the market supply of coffee?

- Who are the major actors involved in the coffee value chain?

- What are the major challenges encountered in upgrading the coffee value chain?

\subsection{Objective of the study}

The general objective of this study is to analyze coffee value chain in Dale Woreda of Sidama Zone, SNNPRS, Ethiopia. The specific objectives are

- To identify factors affecting market supply of coffee in the study area

- To identify the actors in the coffee value chain

- To identify the challenges to upgrade the coffee value chain

\section{Review of Related Literature}

\subsection{Definition of Value chain}

It is of a great importance to have a basic understanding of the concept of value chain, which includes two words, viz, value and chain. Different scholars used different ways of defining value chain. Kaplinsky and Morris (2002) a value chain can be defined as a different activity that are required to take products or services from the stage of production through the involvement of different actors at different stages to transform the inputs to products and delivering them to final customers for use.

To the same scholars, a value chain analysis seeks to characterize how values are created and shared among the participants of the value chain. Another scholars Hobbs and Fulton (2000) define value chain as: "The entire chain of activities from the area of production to the consumption connecting different parties including: whole sellers, retailers and processors in supplying goods and services to final users".

From an alternative perspective, the term value chain refers to the fact that value is added to preliminary products through the combination of other resources (ILO, 2006). The activities that comprise the value chain can be contained within a single firm or divided among different business firms or within a similar geographical location or spread over wider areas. Value chain concept can be seen not as a separate unit but can also be seen a holistic networks and systems of different linked production and exchange activities operating in different geographical areas (ILO, 2006).

\subsection{Concepts of Value Chain}

Porter (1985) defines a value chain is a visualization of the collections of activities that are performed to plan, manufacture, sell, provide and maintain its product. In similar fashion, a value chain represents the production process of a product or a service from raw materials to manufacturing, assembly, the main company or brand in question, retailers and distributors and lastly to the final users. It shows an outline of the primary and secondary activities taken upon by a company in charge of selling a certain product or service to their end customers (Porter, 1985). Moreover, a value chain shows a sum value and consists of margin and value activities.

In essence, the value chain concept by Porter (1985) shows the process components needed for capturing value from products and services. This process chain starts from raw materials to subcontractors and providers, the company in question itself and its distributors and re-sellers, ending at the end customer level, which is the component of the value chain where profit margins are generated from (Porter, 1985).

\subsection{Empirical Review on Value Chain}

A recent study made on analysis of supply side constraints on Ethiopian red pepper and paprika capsicum production and export by Thijs (2010) the study as a methodology combines quantitative and qualitative techniques with the development of hypothesis, also known as a q- squared method. The chain is characterized by insufficient output, low quality and irregularity of supply, the focus of attention lays at the production site, in this case, the farm. Whereas, the constraints mostly focused on production, governance is primarily concerned with product exchange. The research findings indicate that the majority of pepper transactions take place at the local markets. Before indicating how governance is organized in the domestic and international chain, attention is given to the embedding of the local market in the wider institutional environment.

In the study made by Zekarias (2012) titled Hot pepper production and marketing in Southwest Ethiopia: an alternative enterprise for small scale farmers. The study examined hot pepper production and marketing in socioeconomic life of producers and actors. The study employed descriptive statistics, net benefit and margin analysis and the result on market structure indicate that (50\%) of sale directly goes to the local consumers followed by assemblers $(28.5 \%)$ and retailers $(21.5 \%)$. The margin analysis result also shows that the highest profit margin of 68.2 and $100 \%$ when the product sold to retailers and local consumers, respectively. Concerning the problems, the study identified low productivity, illegitimate act of actors, reduced quality of product and irregular price in small market place and long distance as identified as major problems that adversely affects production and marketing of hot pepper in the study area. 
Li and Jenni (2004) have conducted a study on value chain and the internet in companies pursuing a differentiation strategy. They have tried to gain a deeper understanding of value chain and internet technology in companies pursuing differentiation strategy. The researchers have used qualitative research approach method for analyzing the data collected through personal interviews and two hotels were selected. And the finding of the study result showed that internet has affected on the case hotels' value chain is unique and depends on many factors, like the scope, size and scope of business and the hotels did not exploit the full potential due to less application of internet technology in the hotel industry.

In a study conducted by Christin (2006), it has been observed that there is a strong correlation between the complexity of the final product and the governance structure and the benefits and entry barriers for smallholders on the other hand. The study finding revealed that the more complex and the higher the quality of the final product, the stronger the relationship between producers and traders become which resulted in more benefits to smallholders producers. Thus, the study concluded that complexity of the final product plays an important role in upgrading smallholder producer.

Similarily, a study made by Emily and John (2010) focused on the Banana value chains in Central Africa. The results of the study revealed that, the coordination between and among value chain actors were characterized by weak linkages within the banana value chains with poor integration of value chain actors and minimal involvement with regional markets and high value domestic chains. Finally, it was recommended that collective marketing, penetration in to high value chains and improved processing techniques may provide in increasing chain participation.

In addition, there are many studies made on success factors on value chain. Amongst, Leslie (2011) on the wood pallet supply chain, the result revealed that $73.1 \%$ of the respondents sold their products directly to customers and the lead time for raw materials to shipment was reported to be 1 to 10 days for $81.9 \%$ of companies of that were engaged in and the remaining $26.9 \%$ confirmed that they need the involvement of intermediaries. Therefore, it can be concluded that the chain is simple that directly deals with the final users. By similar authors, the study identified seven factors that are most important for purchasing decision including availability, cost, supplier reliability, quality, punctuality, strength, and workmanship. Hence, these should be taken into account while marketing supply decisions.

Another study by Paulin (2011) identified poor market linkages among the value chain actors. The result revealed that low utilization of value addition technologies, poor market opportunities, decreasing incentives for the production and consumption and lack of sufficient competitiveness. Hence, the impact of poor linkages among actors limits the smallholder producers of cassava from expanding and obtaining more market share.

A study made by Mayoux (2003) the chains can be simple when producers directly sell to the consumers but long and complex when the other actors play role in buying, processing, transporting and selling to consumer. When the chain is complex it offers a multitude of choice to farmers. And in this case, they may choose to supply a specific market segment, and produce the crop that is tailored to that division. In another way, they may try to process their produce to add value to it: they may dry pepper rather than selling them fresh. Therefore, farmers need to understand the players in the chain and the requirements of the different branches so that they can supply the product for which the chain require and this will increase their bargaining power in the chain, and improve their price they get for their product. As a final point, this in turn increases farmers' comparative advantage by increasing the amount of supply and quality of the product.

\section{Research Methodology}

The aim of this section is to explain methods used in carrying out this research, how the research was designed, sampling technique and reasons for the choices. The chapter presents data collection and data analysis methods employed in the research.

\subsection{Description of the Study Area}

Dale is part of the Sidama Zone located in the Great Rift Valley, one of the Woredas in the Southern Nations, Nationalities and Peoples' Region of Ethiopia. The Woreda center is located $47 \mathrm{~km}$ south west of the SNNPRS regional capital Hawassa, with the total population of 114,480 (Sidama Zone FEDO, 2012 unpublished report). Dale is bordered on the south by Aleta Wendo and Chuko, on the west by Loko Abaya, on the northwest by Boricha, on the north by Shebedino, and on the east by Wensho. The major town in Dale is Yiregalem. Parts of Dale woreda were separated to create Loko Abaya and Wensho woredas. The elevation of this woreda varies from about 1200 meters above sea level along the shores of Lake Abaya to about 3200 meters at its westernmost point. Dale Woreda is well known in the production of cash crop like corn, barley, haricot beans, local varieties of cabbage, and sweet potatoes. Coffee is also an important cash crop in Dale, with 15.38 square kilometers planted with this crop, which produced a total of 9.3 million kilograms of beans in 2002/03 (5.7 million kilograms in 2003/04). 


\subsection{Research Design}

The types of research employed under this study were descriptive and explanatory research. The major purpose of descriptive design is description of the state of affairs as it exists at present. In the study, descriptive design critically assesses the quantity of coffee supplied by the sample farmers during 2017-2018 harvest season, expressed in quintals and in order to identify factors influencing market supply of coffee whereas explanatory design was employed to investigate the relationship between the quantity of coffee supplied by the sample farmers and the determinants of market supply of coffee to estimate the integrated influence of the five explanatory variables were expected to affect the dependent variable. Moreover, this study utilized cross-sectional survey in the sense that all relevant data were collected at a single point in time (Hopkins, 2001). The reason for preferring a cross-sectional study was due to the wide nature of the study and the constraint posed by time.

\subsection{Population and Sampling procedures}

\subsubsection{Study population}

The study was conducted on value chain analysis of coffee in Dale Woreda of Sidama Zone. In Dale Woreda there are thirty six kebeles found including Danshe sira, Soyama, Semen Mesenkela, Chume, Wayicho, Degara, Duba, Halile, Gidamo, Dagiya, Moto, Shoye, Gane, Ajawa, Debub Mesankela, Semen Kege, Shifa, Debub Kege, Tula, Hedha Kaliti, Kaliti Simita, Wene Nata, Awada, Mesincho, Goyida, Bera Tedicho, Bera Chale, Megera, Wara, Wicho, Gajamo, Shafena, Hailo, Boa Bedegelo, Lelo and Manche. Here, according to DWMCA (2014) report, the total numbers of coffee farmers found in the thirty-six kebeles of Dale Woreda's were reported to be 21083 farmers. The researcher purposively selected 14 of 36 kebele's on the number of households participating in coffee production which enabled the researcher to obtain an appropriate data through increasing the responding farmers and represented $53.39 \%$ of the total household coffee farmers in Dale Woreda. Then, the total number of households in the selected 14 Kebele's were 11258. Employing Yemane (1967) sample size determination formulas

Then, $\mathrm{n}=\frac{11258}{1+11258(.05) 2}=\frac{\mathbf{1 1 2 5 8}}{29.145}=\underline{\mathbf{3 8 6} \text { farmers }}$

\subsubsection{Sampling Design}

The researcher used both probability and non-probability sampling technique. The reason behind these techniques is that it is easy to analyze and give equal chance for the respondents. This study selected some representative (samples) from the total population to draw valuable conclusion about farmers. So to keep accuracy of data 386 respondents farmers were communicated and 286 returned and analysis was made on the returned questionnaires.

\subsection{Data collection procedures}

The study employed both primary and secondary sources for collecting facts and figures relating to the topic under research.

\section{Analysis of the study}

Table 4.1. Pearson correlation on determinants of coffee value chain

\begin{tabular}{|c|c|c|c|c|c|c|c|}
\hline \multicolumn{2}{|l|}{\begin{tabular}{|l|} 
Variables \\
\end{tabular}} & Education & $\begin{array}{l}\text { Age of } \\
\text { plantation }\end{array}$ & Experience & Distance & $\begin{array}{l}\text { Market } \\
\text { information }\end{array}$ & Supply \\
\hline \multirow[t]{3}{*}{ Education } & Pearson Correlation & 1 & $.404 * *$ & $.571 * *$ & $.436 * *$ & $.249 * *$ & $.833^{* *}$ \\
\hline & Sig. (2-tailed) & & 0 & 0 & 0 & 0.001 & 0 \\
\hline & $\mathrm{N}$ & 286 & 286 & 286 & 286 & 286 & 286 \\
\hline \multirow{3}{*}{$\begin{array}{l}\text { Age } \\
\text { of } \\
\text { plantation }\end{array}$} & Pearson Correlation & $.404 * *$ & 1 & $.499 * *$ & $.581 * *$ & $.407 * *$ & $.429 * *$ \\
\hline & Sig. (2-tailed) & 0 & & 0 & 0 & 0 & 0 \\
\hline & $\mathrm{N}$ & 286 & 286 & 286 & 286 & 286 & 286 \\
\hline \multirow[t]{3}{*}{ Experience } & Pearson Correlation & $.571 * *$ & $.499 * *$ & 1 & $.502 * *$ & $.588 * *$ & $.668 * *$ \\
\hline & Sig. (2-tailed) & 0 & 0 & & 0 & 0 & 0 \\
\hline & $\mathrm{N}$ & 286 & 286 & 286 & 286 & 286 & 286 \\
\hline \multirow[t]{3}{*}{ Distance } & Pearson Correlation & $.436 * *$ & $.581 * *$ & $.502 * *$ & 1 & $.279 * *$ & $.464 * *$ \\
\hline & Sig. (2-tailed) & 0 & 0 & 0 & & 0 & 0 \\
\hline & $\mathrm{N}$ & 286 & 286 & 286 & 286 & 286 & 286 \\
\hline \multirow{3}{*}{$\begin{array}{l}\text { Market } \\
\text { information }\end{array}$} & Pearson Correlation & $.249 * *$ & $.407 * *$ & $.588 * *$ & $.279 * *$ & 1 & $.409 * *$ \\
\hline & Sig. (2-tailed) & 0.001 & 0 & 0 & 0 & & 0 \\
\hline & $\mathrm{N}$ & 286 & 286 & 286 & 286 & 286 & 286 \\
\hline
\end{tabular}




\begin{tabular}{|l|l|l|l|l|l|l|l|}
\hline \multirow{2}{*}{ Variables } & Education & $\begin{array}{l}\text { Age of } \\
\text { plantation }\end{array}$ & Experience & Distance & $\begin{array}{l}\text { Market } \\
\text { information }\end{array}$ & Supply \\
\hline \multirow{3}{*}{ Supply } & Pearson Correlation & $.833^{* *}$ & $.429^{* *}$ & $.668^{* *}$ & $.464^{* *}$ & $.409^{* *}$ & 1 \\
\cline { 2 - 9 } & Sig. (2-tailed) & 0 & 0 & 0 & 0 & 0 & 0 \\
\cline { 2 - 8 } & N & 286 & 286 & 286 & 286 & 286 & 286 \\
\hline
\end{tabular}

Source: Survey result, 2018

**. Correlation is significant at the 0.01 level (2-tailed).

The results in Table 4.1. indicate that, there is positive and significant relationship between all factors and again all factors have positive and significant relationship with dependent variable (supply). In addition, Table 4.1 indicated that there is positive and significant relationship between education and supply $(\mathrm{r}=.833, \mathrm{p}<0.01)$, age of plantation and supply $(\mathrm{r}=.429, \mathrm{p}<0.01)$, experience and supply $(\mathrm{r}=.668, \mathrm{p}<0.01)$, distance and supply $(\mathrm{r}=.464$, $\mathrm{p}<0.01)$, market information and customer supply $(\mathrm{r}=.409, \mathrm{p}<0.01)$. In general, from the above finding there is high positive and significant relationship between education and supply followed by experience and supply as compared with the rest.

Table 4.2 Regression Model Summary of factors on coffee value chain

\begin{tabular}{|c|c|c|c|c|}
\hline Model & R & R Square & Adjusted R Square & Std. Error of the Estimate \\
\hline 1 & $.871 \mathrm{a}$ & 0.759 & 0.753 & 0.462 \\
\hline
\end{tabular}

Source: Own survey result, 2018

The above Table 4.2 depicted that the $\mathrm{R}^{2}$ value of 0.759 . According to this result the independent variables (factors affecting supply of coffee) have an effect on supply accounted 75.9 percent and the other unexplained variables which are not considered in the study accounted $24.10 \%$ have affected supply of coffee, the adjusted $\mathrm{R}$ square is 0.753 and standard error of the estimation is 0.462 . To sum it up, in accordance with the above result, supply of coffee in the study area has highly affected by identified factors other than other factors/unexplained variables.

Table 4.3. Regression model for Coefficients.

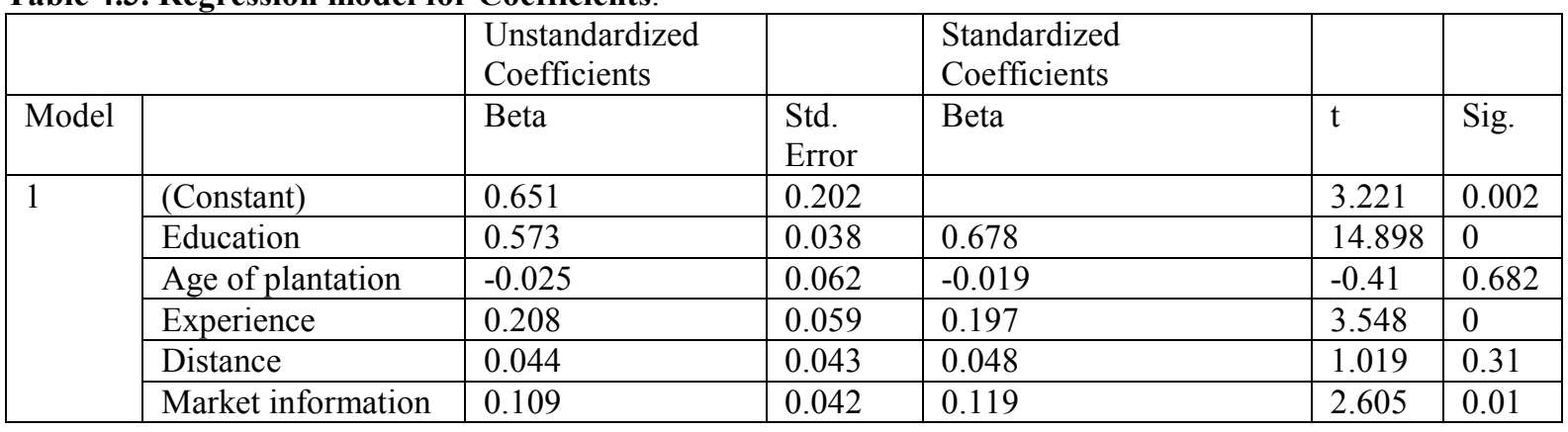

Source: Survey 2018/2019

a. Dependent Variable: Customer satisfaction

The results of regressions analysis, presented in Table 4.3 above, education has a positive and significant effect on supply of coffee with value of beta $=0.573$, standardized coefficient beta $=0.678, p<0.01$, age of plantation has negative and insignificant effect on supply of coffee with value of beta $=-0.025$, standardized coefficient beta $=$ $0.062, p<0.01$, experience has a positive effect on supply of coffee with value of beta $=0.208$, standardized coefficient beta $=0.059, \mathrm{p}<0.01$, distance has a positive and significant effect on supply of coffee with the value of beta $=0.044$, standardized coefficient beta $=0.043, p<0.01$, market information has a positive effect on supply of coffee with the value of beta $=0.109$, standardized coefficient beta $=0.042, p<0.01$. Moreover, from the findings of this study, the researcher found out that not all of the factors affecting supply of coffee have positive impact on supply of coffee. Out of the five factors affecting the supply of coffee (education, experience, distance and market information) have positive and significant impact on supply of coffee. On the other hand, age of plantation has a negative and insignificant influence on supply of coffee. A study made by Elias (2005) indicated that positive relationship between the ages of coffee with coffee of supply which negate the result of this study in relation with age of plantation. The findings of this study also indicated that education is the most important factor to have positive and significant effect on supply of coffee in the study area. 
Table 4.4 Distribution of value addition among major value chain actors

\begin{tabular}{|l|c|c|c|c|c|}
\hline Vale chain & Producers & Collectors & Wholesalers & Retailors & Processors \\
\hline Sales price & 27.85 & 33.85 & 42.40 & 46.87 & 72 \\
\hline Cost of raw material & 22.72 & 32.33 & 32.11 & 36.11 & 46.85 \\
\hline Gross value added & 5.13 & 1.52 & 10.29 & 10.76 & 25.15 \\
\hline Percentage of total value added & $9.71 \%$ & $2.87 \%$ & $19.47 \%$ & $20.36 \%$ & $47.58 \%$ \\
\hline
\end{tabular}

Source: Own survey result, 2018

* Total Value added $=\mathrm{Br} \mathbf{5 2 . 8 5} / \mathrm{kg}$

In coffee production, each coffee value chain actors add value to the product as coffee passes from one actor to another. In other way, the value chain actors change the form of coffee product by introducing different mechanisms like processing or improving the grade of the products which create space and time utility. The value addition distribution among the coffee value chain actors in coffee is depicted in Table 4.4.

As can be seen from Table 4.4, that value addition is the difference between sales price and cost of production at every stage of the value chain. Coffee producers added $9.7 \%$ of the total value of coffee in Dale Woreda. Collectors are adding about $2.87 \%$ of the value while wholesalers add about $2.87 \%$ of the value while wholesalers add about $19.47 \%$. And retailers add $20.36 \%$ while processors add $47.5 \%$. From the finding we can conclude that processors add the majority of the total value of coffee value chain actors in the study area and also we can deduce that the highest profit is earned by processors due to small operational cost while collectors make small profit in comparison with other value chain actors.

Table 4.5 Coffee value chain actors

\begin{tabular}{|l|l|l|}
\hline Value chain actors & Frequency & Percent \\
\hline Whole sellers & 47 & 16.4 \\
\hline Retailers & 17 & 5.9 \\
\hline Processors & 42 & 14.7 \\
\hline Exporters & 2 & 0.7 \\
\hline Consumers & 161 & 56.3 \\
\hline Collectors & 17 & 5.9 \\
\hline Total & $\mathbf{2 8 6}$ & $\mathbf{1 0 0}$ \\
\hline
\end{tabular}

Source: Own Survey Data, 2018

As it is shown in the Table 4.5, about 161(56.29\%) of farmers responded that they are selling coffee to consumers which is followed by 47(16.43\%) who sell to whole sellers and the remaining 42(14.69), 2(0.70\%) sell coffee to processors and exporters respectively but 34 of farmers sell their products to collectors and retailers with an equal 17(5.94\%). From the findings it is possible to conclude that the value chain of coffee in the study area is simple chain that is the product flow is from producer to consumers because the selling activity of most farmers are directed towards consumers. From the above finding, in the study area different value chain actors are participating in distributing product from producers to consumers including producers, wholesalers, retailers, collectors, processors and consumers.

In order to triangulate the data collected through questionnaire, a focus group discussion was conducted with key informant farmers, traders and agricultural and relevant experts. According to them, the major value chain actors actively involved in coffee marketing were farmers, collectors, wholesalers and consumers but retailers and processors with insignificant participation which is somewhat similar with questionnaire survey result. The discussion also found that wholesalers were more beneficial from those value chain actors who actively involved in coffee value chain in the study area and finally through discussions as it is depicted in Figure 4.1 and Table 4.6. Coffee processing activities, functions and actors performing the functions were identified. 


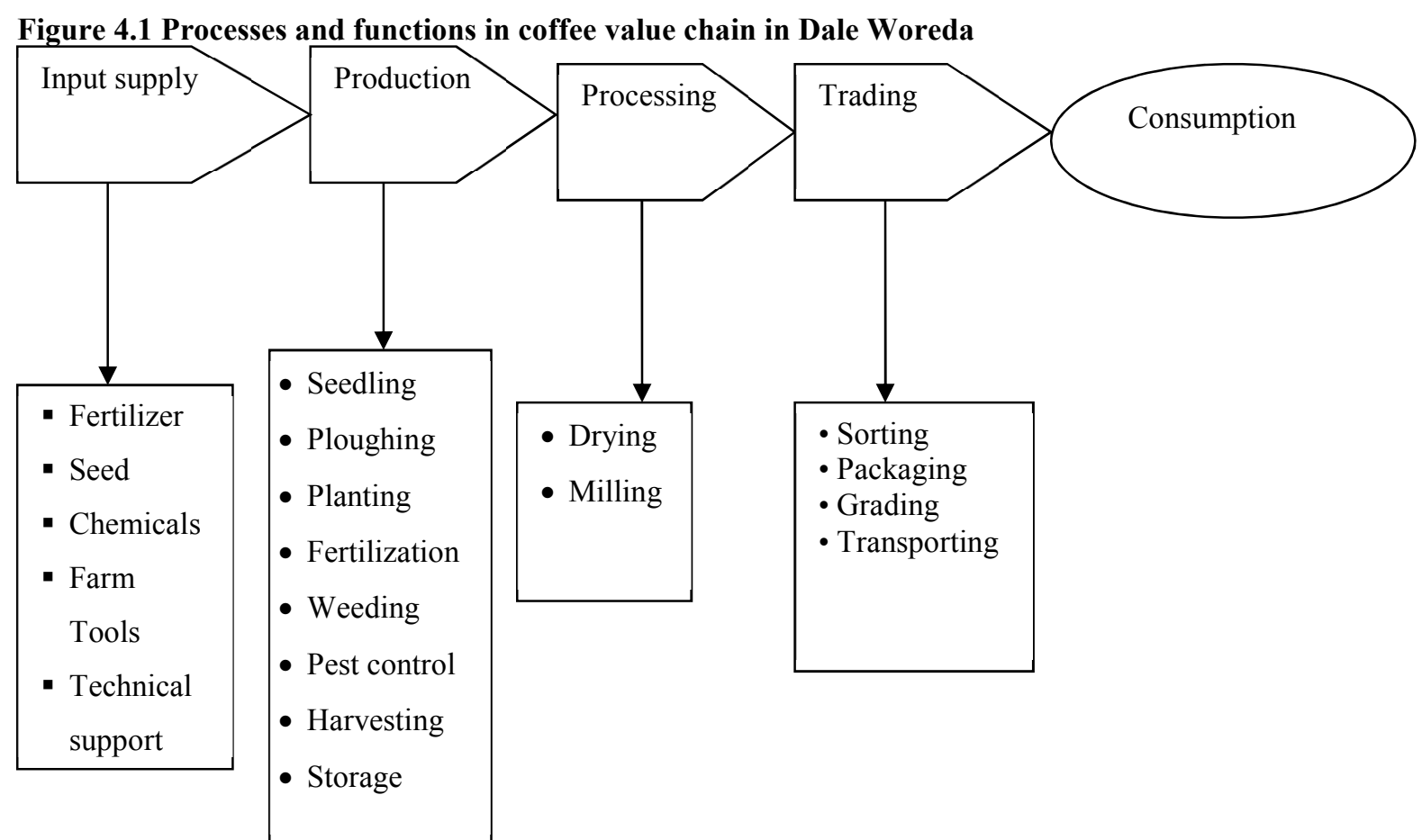

Source: Own formulation based on the focus group discussion made, 2018

Table 4.6 Coffee value chain actors and their functions

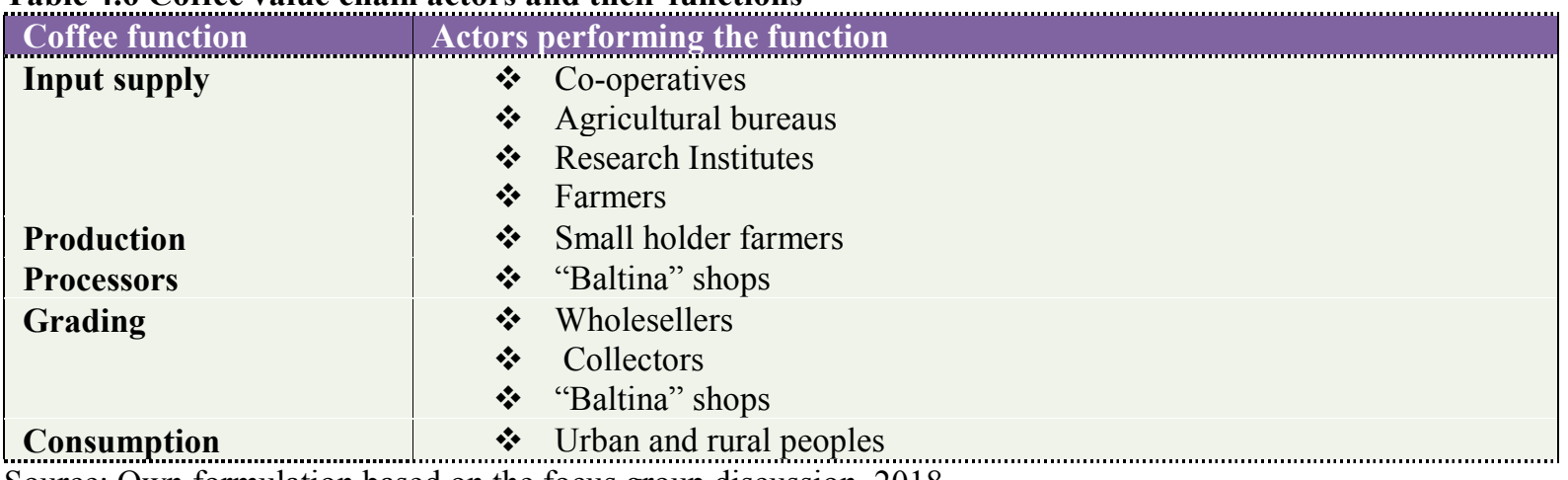

Source: Own formulation based on the focus group discussion, 2018

Table 4.7 Trader responses from whom they buy and to whom they sell coffee

\begin{tabular}{|l|l|l|l|l|l|}
\hline From whom do you buy & Frequency & Percent & $\begin{array}{l}\text { To whom do you sell } \\
\text { coffee }\end{array}$ & Frequency & Percent \\
\hline Farmers & 13 & 43.3 & Wholesalers & 7 & 23.3 \\
\hline Cooperatives & 0 & 0 & Retailers & 5 & 16.7 \\
\hline Wholesalers & 8 & 26.7 & Processors & 3 & 10.0 \\
\hline Retailers & 2 & 6.7 & Exporters & 0 & 0.0 \\
\hline Collectors & 7 & 23.3 & Consumers & 15 & 50.0 \\
\hline Total & 30 & 100 & Total & 30 & 100 \\
\hline
\end{tabular}

Source: Own survey result, 2018

As it is depicted in Table 4.7, that the majority of traders responded that they buy coffee with 13(43.3\%) from farmers which is followed by wholesalers $8(26.7 \%)$ and the remaining $7(23.3 \%)$ and $2(6.7 \%)$ of them from collectors and retailers respectively. With regard to whom they sell coffee, the majority respondent traders sold to consumers with $15(50 \%)$ which is followed by $7(23.3 \%)$ who sold to wholesalers and the remaining $5(16.7 \%)$ and $3(10 \%)$ of them to retailers and processors respectively. From this study we can conclude that the majority of respondent traders buy coffee from farmers followed by wholesalers while assessing to whom they sell, the majority of them sold to consumers and wholesalers. Figure 4.2 has been drawn through combining Figure 4.1 and Table 4.5 to come up with clear picture of coffee flow among the value chain actors in the study area. 
Figure 4.2. Coffee value chain actors marketing relationships

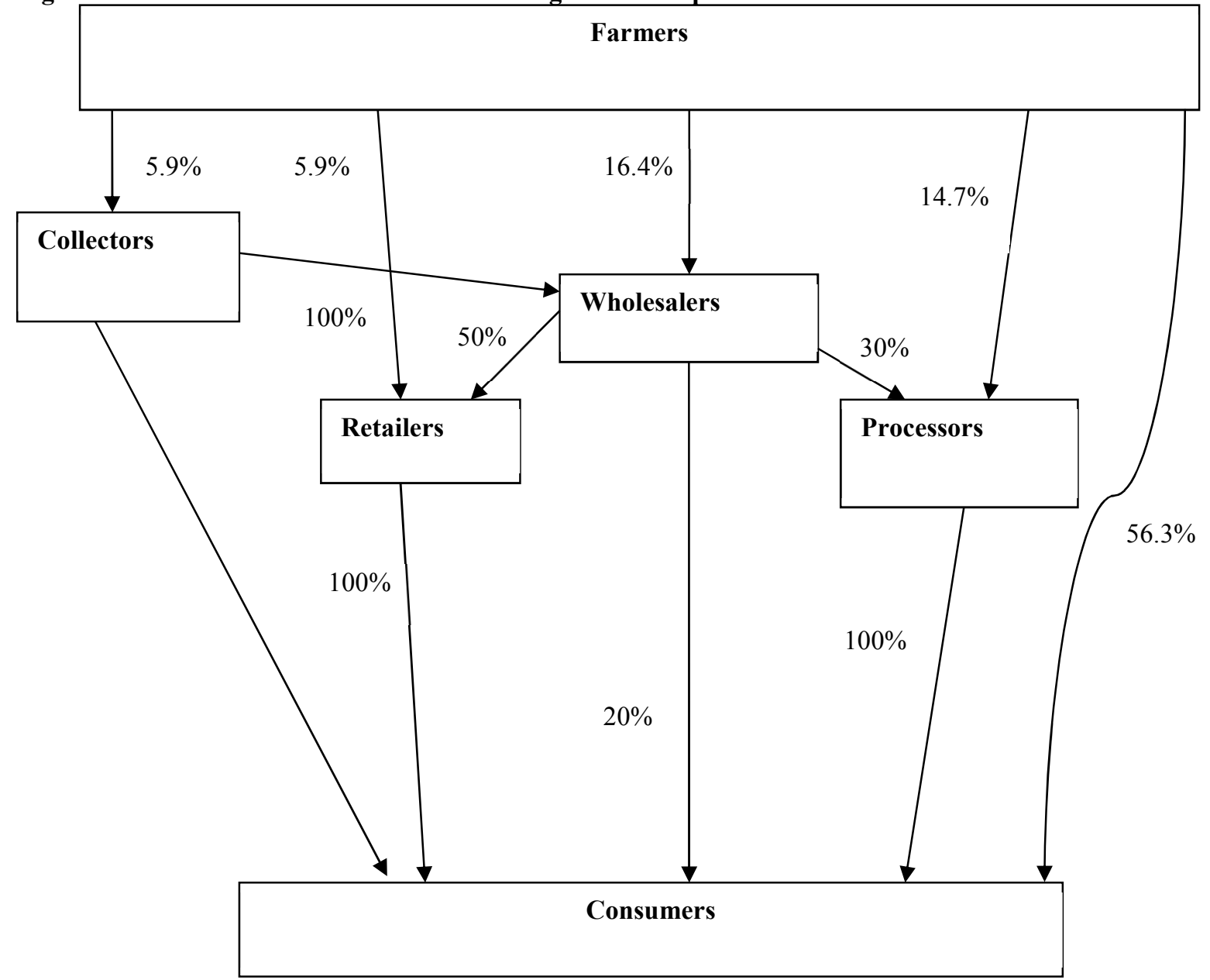

Source: Own drawing from survey result, 2018

Figure 4.2 depicts the value chain of coffee originating from Dale woreda. From figure 4.2. there are 6(six) value chain actors are involved in the coffee production and marketing including farmers, collectors, wholesalers, retailers, processors and the final consumers. From Figure 4.2, it can be seen that the majority of farmers sell their products to consumers with $56.3 \%$ which is followed by wholesalers $(16.4 \%)$, processors $(14.7 \%)$, collectors and retailers with equal $5.9 \%$. Concerning wholesalers, most of them supply coffee to retailers (50\%) followed by processors $(30 \%)$ and consumers $(20 \%)$. With regard to collectors, almost all $100 \%$ of them supply to wholesalers. On the other hand, retailers with $100 \%$ direct supply to consumers. And finally, processors supply directly to final consumers.

As can be seen from Figure 4.2. that there is almost no involvement of organization that support the chain. However, potential actors that can support the chain development have been identified including Bureau of agriculture in assigning agricultural development agents and private and NGO's in providing training on different upgrading strategies and agricultural research institutions in the supply and application of improved seed.

\subsection{Barriers in coffee production and marketing}

4.8.1. Producers entry barriers

Table 4.8. Respondents farmer response on barriers to coffee value chain

\begin{tabular}{|l|c|c|c|c|c|c|c|c|c|c|}
\hline \multicolumn{8}{|c|}{ Barriers to coffee value chain } \\
\hline & $\begin{array}{l}\text { Quality } \\
\text { standard } \\
\end{array}$ & \multicolumn{2}{|l|}{$\begin{array}{l}\text { No skilled worker } \\
\text { available locally }\end{array}$} & $\begin{array}{l}\text { No access to } \\
\text { credit and other } \\
\text { resources }\end{array}$ & $\begin{array}{l}\text { Too much } \\
\text { regulation }\end{array}$ & \multicolumn{2}{l}{$\begin{array}{l}\text { Lack of } \\
\text { infrastructure }\end{array}$} \\
\hline & Freq & $\%$ & Freq & $\%$ & Freq & $\%$ & Freq & $\%$ & Freq & $\%$ \\
\hline Yes & 217 & 75.9 & 271 & 94.8 & 191 & 66.8 & 201 & 70.3 & 266 & 93.0 \\
\hline No & 69 & 24.1 & 15 & 5.2 & 95 & 33.2 & 85 & 29.7 & 20 & 7.0 \\
\hline Total & 286 & 100 & 286 & 100 & 286 & 100 & 286 & 100 & 286 & 100 \\
\hline
\end{tabular}

Source: Own survey result, 2018 
Table 4.8. Indicates the major barriers in the production and marketing mostly faced in the study area by farmers including quality standards, no skilled worker available, and no access to credit, too much regulation and lack of infrastructure. About 271(94.8 percent) of farmers confirmed that no skilled worker availability was the major significant barriers and they put the effect of this barriers were less innovation and low productivity. Another barrier factor that has been found to have adversely affected coffee production and marketing was lack of infrastructure which was confirmed by 266(93 percent) of them and the effect on farmers in terms of high cost of transportation, low market share and low revenue and profit. The third significant barrier was quality standard and also validated by $217(75.9$ percent $)$ of the respondent farmers and they put the effect as difficulty of selling to chain actors and export become expensive, low market access and the fourth significant barrier verified by farmers was too much regulation and no appropriate governance structure and supported by 201(70.3 percent) of the farmers and the put the effect of this barriers as high cost of production and exposure to low price. The fifth significant barrier was no access to credit which was corroborated by 191(66.8 percent) of farmers and they put the effect of such barrier as no finance, low productivity and low motivation to work. This result also similar with the farmers survey result except the availability of skilled worker is not a barrier in case of traders but barrier in case of farmers. Generally, from the result all the stated factors were the major significant barriers in the red pepper production and marketing.

This finding can be somehow supported by Kodigehalli (2011) studied on value chain analysis of coffee. The study had revealed that the most significant barriers to entry to the majority of small producers were consistence in quality, quantity of supply and certification of coffee and relationship with buyers with less influence. From the stated problems, consistence in quality ranked as $1^{\text {st }}$ which were followed by quantity of supply and certification and relationship with buyers with insignificant effect on entry barriers for small holder producers of coffee.

\subsubsection{Traders entry barriers}

Table 4.9 Respondents trader response on barriers to coffee value chain

\begin{tabular}{|l|l|l|l|l|l|l|l|l|l|l|}
\hline \multicolumn{9}{|c|}{ Barriers to coffee value chain } \\
& $\begin{array}{l}\text { Quality } \\
\text { standard }\end{array}$ & \multicolumn{2}{|l|}{$\begin{array}{l}\text { No skilled worker } \\
\text { available locally }\end{array}$} & \multicolumn{2}{l|}{$\begin{array}{l}\text { No access to } \\
\text { credit and other resources }\end{array}$} & \multicolumn{2}{l|}{$\begin{array}{l}\text { Too much } \\
\text { regulation }\end{array}$} & $\begin{array}{l}\text { Lack of } \\
\text { infrastructure }\end{array}$ \\
\hline & Freq & $\%$ & Freq & $\%$ & Freq & $\%$ & Freq & $\%$ & Freq & $\%$ \\
\hline Yes & 23 & 76.7 & 3 & 10.0 & 22 & 73.3 & 27 & 90.0 & 29 & 96.7 \\
\hline No & 7 & 23.3 & 27 & 90.0 & 8 & 26.7 & 3 & 10.0 & 1 & 3.3 \\
\hline Total & 30 & 100 & 30 & 100 & 30 & 100 & 30 & 100 & 30 & 100 \\
\hline
\end{tabular}

Source: Own survey result, 2018

Table 4.9 shows traders response on barriers of coffee marketing. From 30 respondent traders $23(76.7 \%)$ of them responded that there is a quality standard barrier in coffee marketing and the remaining 7(23.3) it is not a major problem. Concerning the skilled worker availability, the majority $27(90 \%)$ of responded that skilled worker availability in the study area is not a barriers and regarding access to credit and other resources $22(73.3 \%)$ of them responded that this factor can be a major barrier and the remaining $8(26.7 \%)$ of them did not agree with this.

When we further assess barriers to coffee marketing, 27(90\%) of them responded the existence of too much regulation was a barrier while the remaining $3(10 \%)$ of them not and then concerning the availability of infrastructure, 29(96.7\%) responded that lack of infrastructure facilities especially of road becomes the major barrier in the study area. Therefore, it can be gleaned from the above result that quality standard, access to credit and other resources, too much regulation and lack of infrastructure were the major barrier while the availability of skilled worker is less barrier in the study area.

\subsection{Findings}

The study was designed to analyze coffee value chain so as to identify actors and challenges to upgrade the chain in Dale Woreda of Sidama Zone. The primary data were collected via questionnaire from the coffee farmers and interview were conducted with key informant groups.

According to inferential analysis of the study, there is positive and significant relationship between factors identified (independent variables) and supply of coffee (dependent variable). The correlation results of the study indicated that there is positive and significant relationship between factors affecting supply of coffee (education, experience, distance and market information) themselves and again with the dependent variables (supply). Strong relationship were found between education and supply. While, weak relationship found between age of plantation and supply (Table 4.3). In general, the results revealed that all independent variables accounted for 75.9 percent of the variance in supply of coffee $(\mathrm{R} 2=0.759)$. Thus, 75.9 percent of the variation in supply of coffee can be affected by the identified factors other unexplored variables may explain the variation in supply of coffee which accounts for about 24.1 percent (Table 4.2).

With respect to value chain addition among major value chain actors, the study revealed that processors are the dominant one with $47.58 \%$ value addition followed by retailers $(20.36 \%)$ and wholesalers $(19.47 \%)$ with smaller value addition by collectors with $2.87 \%$ of the total value added. 
Regarding entry barriers, it is disclosed from farmer's response that low skilled worker availability is the dominant barrier followed by lack of infrastructure and quality standard while in case of trader's lack of infrastructure is the dominant entry barrier followed by too much regulation.

\subsection{Recommendations}

Based on the findings of the study to achieve a win-win situation of sustainable management principally in coffee value chain and maintain the livelihood of actors in the value chain the following recommendations are drawn that should be taken in to consideration by respective concerned bodies in the study area Dale Woreda, Sidama Zone.

The result of value addition distribution among the value chain actors revealed that, processors generates the higher percentage of total value addition and this could be a profitable way for smallholder producers to undertake processing activities. Accomplishing that could benefit this include the distribution of processing technology, methods and costs and for new and existing local processing actors like "Baltina". The activity would need to go with market awareness campaign to inform consumers and also needs the involvement of organization through providing training to smallholder producers to increase their value addition in red pepper production.

The Agricultural bureau should improve the age of plantation by in the supply of coffee to make them competent enough to improve the production. Strengthening linkage between research centers, farmers and agriculture office is also important. Since strong linkages between institutions and organizations working on coffee sector are vital to enhance coffee sector development especially in creating productivity in relation with age of plantation.

\section{References}

Babur, D. 2009. Effectiveness of farmer field school in promoting coffee management practices in the case of Jimma and Sidama Zone, Master thesis, Haromaya University.

Baloyi, J. 2010. An Analysis of Constraints Facing Smallholder Farmers in Agribusiness Value Chain: A case Study of Farmers in Limpopo Province. A Master thesis in Agricultural Economics submitted to University of Pretoria. pp 104.

Christin, S. 2006. Value chains for a better integration of smallholders to trade- the case of Chilli in Ghana. Msc thesis submitted to Humboldt University Berlin, pp 124.

Daviron B and Ponte S. 2005. The Coffee Paradox, Palgrave Macmillan, New York.

Demeke, T. 2007. Performance of coffee Marketing co-operatives and member's satisfaction in Dale District of SNNPRS, Ethiopia, MSC thesis, Haromaya University.

Elias, A. (2005). Economics of Coffee Marketing: A Case Study of Goma District in Jimma Zone of Ethiopia. An MSc Thesis Presented to the School of Graduate Studies of Haramaya University, 56.

Emily, O and John, J. 2010. Banana value chains in central Africa: constraints and opportunities. Paper presented at the 3rd Africsn Association of Agricultural Economists (AAAE) and 48th Agricultural Economists Association of South Africa (AEASA) conference, Capetown, South Africa, pp 12.

Hailu, E. 2007. Analysis of risk and supply response agriculture; for empirical investigations from the Ethiopian coffee growing zones, in case studies of (Jimma, West Hararege, Sidamo, Illubabor, Wolayta). Master thesis Addis Ababa University.

Hobbs J, Cooney A and Fulton M. 2000. Value Chains in the Agricultural Food Sector. What are they? How do They Work? Are they for me? Department of Agricultural Economics, University of Saskatchewan.

ICO (International Coffee Organization). 2009. International Coffee Organization Price Indicator, Price Monthly and Annual Average in 2004-2007.

ILO. 2006. "Decent Work and Poverty Reduction Strategies" (PRS): An Advocacy Guide Book.

ITC, 2002. Coffee: An Exporter's Guide. Geneva: International Trade Centre.

Jemal H. 2013. Coffee Value Chain Analysis: The Case of Meta District, East Hararge Zone of Oromia Regional State, Ethiopia. An MSc Thesis Presented to the school of Graduate Studies of Haramaya University, 35-37.

Kodigehalli, B. 2011. Value chain analysis for Coffee in Karnataka, India. An M.Sc. Thesis Presented to Humboldt university of Berlin, Germany, pp 76.

Kaplinsky, R. and Morris, M. 2002. A Handbook for Value Chain Research, IDRC, Germany.

Leslie, S. 2011. Identifying success factors in the wood pallet supply chain. MSc thesis submitted Virginia polytechnic institute and state university, U.S.A, pp 213.

$\mathrm{Li}$ shi and Jenni M. 2004. Value chain and the internet in companies pursuing a differentiation strategy case studies of Finnish Hotels: An Msc programme in Electronic Commerce: Lulea university of technology. pp 102.

Mayoux, L. 2003. Trickle-Down, Trickle-up or Puddle? Participatory Value Chain Analysis for Pro-poor Enterprise Development. IDS Publication, Sussex, U.K.

Oxfam international. 2002. The coffee crisis in Kafa province of Ethiopia. By Ruth, M., Abera T. and Gezahegn $\mathrm{K}$ published by research center, Addis Ababa. 
Oxfam report. 2009. International commodity research study on market background of coffee, non-government organization publication.

Paulin, N 2011. A value chain and market integration analysis of the cassava market in the Democratic republic of Congo. Msc thesis submitted to university of Pretoria, South Africa pp 114.

Porter, Michael E. 1985. Competitive Advantage: Creating and Sustaining Superior Performance. The Free Press: New York, NY.

Roukens, O. 2005. Export Potential of Ethiopian Oleoresins, Ethiopian Export Promotion Department. pp. 7-14.

Singh, R.H; Rankine, L.B and Seepersad. 2006. The Caricom Regional Transformation Program for Agriculture Market Intelligence Report pp 66.

Tadesse, K., Zerihun, G., Herman, D., \& Van, S. 2007. Spatial Integration of Coffee-Grower's Markets in Ethiopia. Thijs, R. 2010. An Analysis of Supply Side Constraints on Ethiopian Red Pepper and Paprika Capsicum Production and Export: a Global Value Chain Approach. An International Development Studies Master Thesis Submitted to Utrecht University, Netherland. pp 112.

Webber, M. C. and P. Labaste. 2010. Building Competitiveness in Africa's Agriculture. A guide to value chain concepts and applications. World Bank Agriculture and Rural Development publication series. ISBN 978-08213-7952-3 (pbk.) ISBN 978-0-8213-7964-6 (electronic).

Willem, J. 2011. Ethiopia Coffee Buying Manual; Practical Guidelines for the Purchasing and Importing of Ethiopian Specialty Coffee.

Zekarias, S. 2012. Hot Pepper Production and Marketing in Southwest Ethiopia: An Alternative Enterprise for Small Scale Farmers. Trends in Agricultural Economics, 2012 ISSN 1994-7933. Asian Network for Scientific Information.

Zerihun, G., \& Tadesse, K. 2009. Price Transmission and Adjustment in the Ethiopian Coffee Market. Contributed Paper Presentation at the International Association of Agricultural Economists Conference (p. 3). Beijing, China, August 16-22, 2009. 